"The Defection of Women": the New Zealand Contagious Diseases Act Repeal Campaign and Transnational Feminist Dialogue in the Late Nineteenth Century

James Keating (UNSW)

j.keating@unsw.edu.au

Author accepted manuscript of " "The Defection of Women": the New Zealand Contagious Diseases Act Repeal Campaign and Transnational Feminist Dialogue in the Late Nineteenth Century,' Women's History Review 25, no. 2 (2016): 187-206. 


\begin{abstract}
:
Over the past decade, historians have situated feminist reformers' efforts to dismantle the British imperial contagious diseases apparatus at the heart of the transnational turn in women's history. New Zealand was an early emulator of British prostitution regulations, which provoked an organised repeal campaign in the 1880s, yet the colony is seldom considered in these debates. Tracing the dialogue concerning the repeal of contagious diseases legislation between British and New Zealand feminists in the 1890s, this article reaffirms the salience of political developments in the settler colonies for metropolitan reformers. A close reading of these interactions, catalysed by the Auckland Women's Liberal League's endorsement of the Act in 1895, reveals recently enfranchised New Zealand women's desire to act as model citizens for the benefit of metropolitan suffragists. Furthermore, it highlights the asymmetries that remained characteristic of the relationship between British feminists and their enfranchised Antipodean counterparts.
\end{abstract}




\section{'The Defection of Women': the New Zealand Contagious Diseases Act repeal campaign and transnational feminist dialogue in the late nineteenth century}

Despairing of the faltering imperial campaign to abolish state-regulated prostitution, in 1895 the British social purity activist Josephine Butler decried the tendency for women's organisations to advocate regulation. 'Worst of all', she informed a confidante, were 'New Zealand women...the first use they make of [the vote] is to publish in all the newspapers a Resolution in favour of the Contagious Diseases Acts'. ${ }^{1}$ By the mid-1890s, Butler was the celebrated leader of a campaign to repeal colonial Contagious Diseases Acts, having redirected the victorious domestic repeal network to address the plight of colonised women in the British Empire. Her attack on New Zealand referred to a resolution, passed by the Auckland Women's Liberal League (AWLL), offering support for an amended New Zealand version of that Act. The resolution sparked a British campaign to impress the necessity of repeal upon the colony's politicians and newly enfranchised women. Previously peripheral to Butler's project, British interest in the colony coincided with the enfranchisement of New Zealand women in 1893, and the possibility it offered for repealers to articulate a strong message to intransigent colonial administrators and pro-regulationists across the Empire.

As Antoinette Burton has argued, the Christian feminists who led the abolition campaign were not merely altruistic, but advocated for imperial reform to justify their claim for political citizenship. ${ }^{2}$ Suffrage and abolitionism were thus intimately linked for many feminists and social reformers. After 1893, the enfranchisement of New Zealand women presented an opportunity to reinvigorate the flagging repeal movement, and to observe the efficacy of women's enfranchisement in elevating public discourse, purifying society, and achieving women's emancipation, as advocates in both societies had foretold. For their part, New Zealand women were attuned to international interest in their emergence as electors, and believed they had a duty to disenfranchised women elsewhere to burnish their reputation as political citizens. 
In the aftermath of the New Zealand suffrage campaign, several of its most prominent figures travelled to London, and were acclaimed in the feminist circles where they recounted their victory. ${ }^{3}$ Suffrage gave New Zealand women impetus to showcase their credentials as imperial citizens.

The British response to the AWLL's resolution reveals the corresponding importance of developments in the white settler colonies for metropolitan reformers. Previous examinations of the imperial repeal campaign have scrutinised the asymmetric relationship between white abolitionists and the colonised non-white women they sought to save from the predations of empire, especially in India. In their activism, compassion for 'degraded' Indian women was allied with a deep concern that the existence of colonial regulation foreshadowed the Act's domestic reinstatement. ${ }^{4}$ New Zealand women were not benighted subjects requiring salvation, yet neither did their enfranchisement 'immediately... alter the pattern of imperial domination evident in feminist contacts', as Barbara Caine has claimed of their Australian contemporaries. ${ }^{5}$ As well as praise, universal suffrage provoked greater scrutiny, and instruction, from metropolitan women who remained unconvinced of their counterparts' commitment to a broader emancipatory agenda. Fearing the consequences of New Zealand women's support for regulation, Butler responded precipitately, considering neither domestic efforts to achieve repeal, nor the Act's local peculiarities, which rendered abolition a less urgent concern than in Britain. Though their salience to metropolitan debates about social reform and women's emancipation increased with their incorporation into the electorate, New Zealand women remained colonial in their relations with British women.

Britain and sixteen of its overseas possessions enacted contagious diseases legislation in the 1860s. Alarmed by venereal disease epidemics among soldiers returning from India and Crimea, the British Parliament passed Contagious Diseases Acts in 1864, 1866, and 1869. A 
product of Victorian faith in the power of scientific principles to direct social improvement, the Acts empowered police to order the genital examination of suspected prostitutes, though not their clientele. Women found to be carrying venereal diseases were interned and treated in 'lock hospitals' until discharged by an army surgeon. The Acts were intended to inhibit the spread of disease in the military and were enforced only in the vicinity of gazetted garrison towns. ${ }^{6}$ Formalised in Hong Kong, Corfu, and Malta before adoption in Britain, by 1870 'virtually every British colonial possession', including New Zealand, had enacted contagious diseases ordinances. $^{7}$

In 1869, organised public opposition to the Act emerged amid the struggle for women's political and economic rights. A coalition of feminists, middle-class reformers, and trade unionists opposed the acts because they sanctioned immorality, degraded women and violated their individual liberty, encoded a sexual double standard, and crucially, failed to reduce transmission rates or eradicate prostitution. In 1883, the House of Commons suspended compulsory examination and the Acts were repealed in $1886 .{ }^{8}$ After they won domestic repeal, the reformers turned their attention to the plight of colonised women under regulation. In their mission to rescue Indian women, Antoinette Burton argues, British women strategically claimed their political emancipation as the moral saviours of the empire. Though they harboured genuine sympathies for Indian women, or at least the stereotypes constructed by the women's press, feminists predicated their internationalism on a conviction in their moral and intellectual supremacy. ${ }^{9}$ More recently, Philippa Levine's comparative study of contagious diseases ordinances situated India alongside Hong Kong, Queensland, and the Straits Settlements, tracing a transnational history of state-regulated prostitution alongside a discussion of its underlying gender and racial assumptions. Both demonstrate that empire existed at 'home' and 'abroad', that the imperial repeal campaign reflected domestic anxieties, and consequently, 
the importance of considering metropolitan feminists' overseas interventions in an imperial context. ${ }^{10}$

New Zealand's omission from these accounts is regrettable but not surprising. As several scholars have recently articulated, the new imperial historiography continues to concern Britain, deploying colonial histories for 'metropolitan purposes'.11 The New Zealand abolition campaign reignited in the mid-1890s, at a moment when the global flare of abolitionism coincided with increased metropolitan interest in Antipodean democratic expansion. ${ }^{12}$ The colony lacked the geopolitical or symbolic resonance of India, but in 1893 it was the only place where enfranchised women could be detained under the Contagious Diseases Act. This invested New Zealand with added significance for British reformers and suffragists alike, who believed antipodean repeal would galvanise the imperial campaign and inspire disenfranchised women, and ultimately appropriated the colonial campaign to promote these ends. Though the history of prostitution and the legislative attempts to combat the concomitant spectre of venereal disease feature prominently in New Zealand historiography, such studies overlook the imperial context in which the Act was devised, operated, and resisted. ${ }^{13}$ New Zealand historians have discussed the transnational circuits of knowledge that informed domestic feminist thought and action from the mid-nineteenth century and have recognised the Act's British antecedents, yet few studies explore the interplay between disenfranchised metropolitan women and their enfranchised colonial counterparts. Yet, as Caroline Daley recently suggested, the reexamination of women's history can overlay an imperial dimension to a nationally preoccupied historiography, and elucidate the complexities of the on-going colonial relationship between white settler societies and the meteropole at the turn of the century. ${ }^{14}$

\section{The New Zealand Contagious Diseases Act, 1869-1886}

Though it derived from an imperial regulatory agenda, New Zealand's contagious diseases debate occurred at a remove from British anxieties regarding military vitality. By 1867 the 
British government had substantially withdrawn the 10,000 troops garrisoned in the North Island during the New Zealand Wars. ${ }^{15}$ Instead, pressure to bolster the legal arsenal to suppress prostitution came from urban elites in Christchurch and Dunedin. Seeking to reduce the gender imbalance within the settler population, exacerbated by the 1860 s gold rushes, the South Island provinces attracted 12,000 single, working-class women between the mid-1850s and 1870 through assisted migration schemes. Intended to provide the colony with much needed female domestic and reproductive labour, as well as smooth the coarse edges of a male-dominated society, the influx of unmarried women instead sparked a moral panic concerning urban prostitution, and the threat refractory women posed to respectable citizens. ${ }^{16}$ Public anxieties prompted an investigative committee to assemble in Christchurch in 1867, which recommended that parliament consider 'medical supervision' to suppress prostitution. ${ }^{17}$

Acquiescing to the petitioners, parliament convened a Select Committee on Social Evil, which met in July 1869 . Instructed to consider measures to regulate brothels and curtail the spread of venereal disease, the committee only summoned evidence from the South Island. Despite submissions opposing medical suppression and the absence of epidemiological data, anecdotal evidence of rising infection rates and glowing reports of the British Acts' implementation swayed the committee. ${ }^{18}$ In August it recommended parliament adopt a Contagious Diseases bill and an amended Vagrant bill, drafted by the Christchurch activists. Both passed through parliament within a month, with the Contagious Diseases Act's proponents lauding its similarities to the 1866 British Act. ${ }^{19}$ As in Britain, women deemed 'common prostitutes' were subject to a police-led regime of genital examination, medical detention, and treatment. The Act contained no explicit references to race, yet as Philippa Levine has observed of its Queensland counterpart, it implicitly targeted working-class white women as opposed to non-white prostitutes, the subjects of most imperial ordinances. In the late eighteenth and early nineteenth centuries European sailors and settlers had traded goods with Māori men in exchange 
for sex with Māori women. However, it is generally accepted that by the mid-nineteenth century, European women constituted the vast majority of prostitutes. As reflected in the preceding provincial debates, and the brothel surveillance records police provided the Select Committee in 1869 , class rather than racial anxieties precipitated the New Zealand Act. ${ }^{20}$ Although the New Zealand legislation emulated the British model, it exceeded the original in its invasiveness and application. For example, reflecting legislators' desire to extirpate street prostitution by corralling sex workers toward brothels, New Zealand, like Queensland in 1868, applied the Act to the civilian population - threatening all women with the prospect of forcible examination. ${ }^{21}$

Despite the Act's swift passage, it did not immediately reinforce the existing vagrancy and disorderly behaviour ordinances authorities deployed to suppress prostitution. First, provincial governments, responsible for police, jails, and lock hospitals, had to request the Governor to declare the Act operational. Betraying a lack of public enthusiasm and fears about the costs of medical internment (that undermined regulatory systems from Bengal to Brisbane), only two of the colony's nine provinces adopted the Act. ${ }^{22}$ Canterbury requested the Act's implementation in 1872, waited six years to report an offence, and revoked it in 1885 after the central government ceased subsidising the Addington lock hospital. Auckland invoked the Act in 1882 , but suspended its operation for financial reasons in $1886 .{ }^{23}$ Although municipalities displayed an increased willingness to quash public immorality in the late century, conviction rates under the permissive Act remained low. While courts convicted over 3000 women'mostly prostitutes' - under the Vagrant Act by the 1870s, in fourteen years of operation, just 224 women were apprehended and 197 convictions recorded under the Contagious Diseases Act, and it remained dormant for a decade before again inflaming the public consciousness. ${ }^{24}$

\footnotetext{
'The Eyes of the World Are on New Zealand': representing women's enfranchisement overseas
} 
After New Zealand's pioneer implementation of universal suffrage in 1893, suffragists and antisuffragists alike described its effects to metropolitan audiences. Male commentators typically emphasised the fortuity of the reform and women's propensity to follow existing electoral patterns. ${ }^{25}$ Yet, aware that their enfranchisement had drawn the metropolitan gaze, former suffragists propagated a suffrage narrative that would encourage their overseas counterparts. ${ }^{26}$ When revising her 1889 pamphlet Ten Reasons Why Every Woman in New Zealand Should Vote in 1893, the colony's leading suffragist Kate Sheppard argued an election held in 'the first complete nation' to enfranchise women would 'attract the attention of the civilised world as to the political effect produced', behoving women to turn out on polling-day. ${ }^{27}$ Determined to mobilise voters in the two months between enfranchisement and the general election, the Women's Christian Temperance Union (WCTU) reminded voters 'the eyes of the world are on the women of New Zealand, to see whether Women's Suffrage is to be for good or evil'. Pressure to exercise the vote 'responsibly' also came from outside the colony. In October 1893, the South Australian WCTU secretary, Mary George, reminded New Zealand women that their exercise of 'this great right' would influence 'the progress of the measure in other lands to a great extent'. After the election, Sheppard published a narrative of her voting experience not for domestic edification, but to 'benefit...women in other countries' ${ }^{28}$ Consequently, she was a popular speaker during her 1894-95 sojourn in Great Britain. In her public pronouncements she encouraged the beleaguered British suffragists by emphasising the renewed vigour for redemptive social reform in post-suffrage New Zealand rather than dwelling on the challenges that confronted enfranchised women, notably their exclusion from the legislature. ${ }^{29}$

Privately, some New Zealand feminists expressed ambivalence about their wider responsibilities, sentiments typified by Anna Stout, the former president of the Dunedin Women's Franchise League (WFL). An indefatigable advocate of New Zealand women's achievements, Stout refrained from communicating her misgivings about female voters to 
international audiences, as she explained to the US-based Australian feminist Margaret Windeyer. Commissioned to write 'a paper on the effects of the Woman's Franchise in NZ' for Windeyer's American friends, after the 1896 general election Stout claimed to be unable 'to think or write about the matter', so devastated was she by female voters' rejection of prohibition at the accompanying local option plebiscite. ${ }^{30}$ The resulting 'blow to our ideals of the elevating effects of the woman's voice in politics', reminded her that women were 'no better than men and are influenced as easily \& for quite as bad motives'. She nevertheless agreed to mask her misgivings for the sake uplifting overseas suffragists, promising Windeyer an essay detailing 'the good effects \& behaviour of the more enlightened educated women' ${ }^{31}$

The desire to entrench a woman-centred suffrage narrative prompted feminists to challenge perceived misrepresentations in the metropolitan press. In her study of overseas accounts of New Zealand women's enfranchisement, Raewyn Dalziel identified an 1894 article in the British periodical Nineteenth Century as a forerunner in establishing the notion that suffrage was a gift bestowed by generous male politicians. ${ }^{32}$ The article's author, Robert Bakewell, a prominent anti-suffragist, dismissed women's agency and issued dismal predictions concerning their future political behaviour. While Dalziel noted British suffragists' critique of Bakewell, she did not document New Zealand women's attempts to contest the rejection of their agency. Alarmed by cabled extracts of Bakewell's article, the Auckland Women's Political League (AWPL) held a public meeting censuring the article, and sought the retraction of his assertion that ninety-five per cent of women 'were averse to the franchise'. ${ }^{33}$ Though ignored in Britain, the League's response, formulated months before the magazine arrived in the colony, indicated feminists' attentiveness and sensitivity to overseas representations of their achievements.

The following month, New Zealand women sought to uphold their reputation as political citizens in the pages of the American WCTU's internationally circulated newspaper, Union Signal. The 15 March edition featured a letter from the New Zealand Union's disaffected ex- 
president, Emma Packe, who offered as 'an actor in the scene some account of the first general election in which enfranchised British women had a share'. Packe blamed women's lacklustre support for prohibition on their lack of 'clear idea[s] of measures for governing the country...suddenly brought to their notice'. ${ }^{34}$ When the edition arrived in mid-May, the New Zealand union lambasted the Union Signal's 'singular carelessness' in publishing the slur uncontested. ${ }^{35}$ In response, local unions wrote to Union Signal, refuting the attack on their character and Packe's 'uncalled for...allusion made to the enfranchisement of Woman', which, they argued, had been exercised 'on the side of righteousness \& truth' ${ }^{36}$

With Packe en-route to Britain, the WCTU took further action to protect their reputation. Afraid she would impart 'a totally incorrect impression of affairs in New Zealand,' the Union's president, Annie Schnackenberg, asked the British Women's Temperance Association to disqualify Packe from working as 'an accredited White Ribbon woman...while thus misrepresenting the...Colony'. ${ }^{37}$ Kate Sheppard, by 1894 ensconced in English feminist circles, asked a similar favour of the World's WCTU vice-president Lady Henry Somerset, who concurred 'Mrs Packe may do harm here', and promised to 'acquaint Miss [Frances] Willard with the gist of your letter'. ${ }^{38}$ If Somerset conveyed these concerns to Willard, the World's WCTU president and Union Signal editor-in-chief, Willard refused to indulge the New Zealanders' plea to 'give as great publicity to this refutation as...to the slander'. ${ }^{39}$ Willard alluded to their complaint in September, in a published apology to Emma Packe for airing her 'private' communication. Pointedly endorsing Packe's sentiments, Willard explained her enlightening 'offhand style' was 'too good to keep,' inducing her to take the liberty of 'changing the words "Dear President" to "Dear Union Signal"' before publication. ${ }^{40}$ As during the suffrage campaign, New Zealand feminists fostered contact with women overseas, particularly in Britain. Conscious of metropolitan interest in their political behaviour, feminist leaders sought to uphold their reputation, and smooth the path for their fellow suffragists. Yet, 
as the 1895 Contagious Diseases Act scandal revealed, British feminists continued to patronise distant New Zealand, and appropriate its example for their own ends.

\section{The 'Defection of Women': Josephine Butler and the New Zealand repeal campaign}

Perhaps because of the New Zealand Act's sporadic application, or public acquiescence with its operation, the repeal effort never reached the pitch of its British predecessor. ${ }^{41}$ However, repealers were spurred into occasional bouts of activism. As the British regulatory system crumbled, the Auckland City Council's decision to enforce regulation galvanised the Act's opponents, drawn from religious and women's groups, provoking an unsuccessful repeal bill in $1883 .^{42}$ New Zealand repealers corresponded with their British counterparts, rehearsed their rhetoric and methods - public meetings, parliamentary petitions, and letters to the press - and constituted local branches of metropolitan organisations, notably Auckland's Association for the Abolition of the State Regulation of Vice. ${ }^{43}$ In 1886, the WCTU's inaugural convention demanded repeal. Months later, retrenchment at the Auckland Council forced the Act's abeyance, and while attempts to invoke its provisions arose sporadically over the following decade, none were successful. ${ }^{44}$

Coincident with the Act's suspension, the WCTU shifted its attention from specific reforms to the broader goal of social purification through women's political emancipation. Despite its nominal focus on temperance, the WCTU was fundamentally concerned with social purity, to be realised by eliminating intoxicants and immoral influences from the body, family, and society. ${ }^{45}$ Members viewed the franchise as the best tool to expedite this transformation by giving 'women the power to repeal bad laws and make good ones' ${ }^{46}$ It has been argued that enfranchisement came early in New Zealand because the suffragists framed the vote as an extension of women's familial responsibilities, even where they harboured radical intentions, rather than a departure from tradition. ${ }^{47}$ Thus, the unambiguous connection delegates at the Union's 1886 convention drew between enfranchisement and abolitionism faded from 
prominence in the 1890s. ${ }^{48}$ While careful to avoid tainting the suffrage movement by association with 'social evil', the WCTU continued to pass resolutions and circulate small petitions demanding repeal. With the vote almost won in 1893, and confronted by a renewed attempt to restore Canterbury's contagious diseases apparatus, the Union reminded members the Act exposed women's 'political disability' and illustrated the urgency of their cause. ${ }^{49}$

Though the dormant Contagious Diseases Act represented more than a symbolic injustice to its opponents, without the immediate threat of medical detention repeal lacked urgency. Supported by small petitions, the former premier Sir George Grey unsuccessfully introduced annual repeal bills to parliament between 1886 and 1889, after which the parliamentary campaign halted until $1895 .{ }^{50}$ Notably, the most vociferous repeal advocate during these years was a recent migrant, Mary Steadman Aldis. A veteran of Josephine Butler's Ladies' National Association for the Repeal of the Contagious Diseases Acts (LNA), she remained in close contact with British abolitionists and pursued colonial repeal as a lecturer and excoriating newspaper correspondent after her arrival in 1884. In 1886 Aldis instigated popular protest against the Act in Auckland by bringing the topic before the local WCTU, importing LNA propaganda, and encouraging opponents to adopt metropolitan tactics. However, her growing notoriety and public criticism of the temperance movement and the WCTU's anti-barmaid campaign irritated the Auckland branch, which distanced itself from her repeal work and excluded her from its suffrage campaign in the late $1880 \mathrm{~s}^{51}$

As New Zealand feminists reconsidered their agenda, Josephine Butler published a manifesto urging the extant British repeal network - the LNA and the closely associated British Committee of the British, Continental and General Federation for the Abolition of State Regulation of Vice - to expand their struggle overseas. Determined to capitalise on their success, she outlined the 'second chapter of our great Abolitionist crusade', the elimination of all imperial regulatory systems. Unable to travel extensively, Butler nevertheless dictated the 
repeal agenda through her speeches, pamphlets, and contributions to the social purity presstactics later employed against the AWLL. ${ }^{52}$ Above all, reformers targeted India, the linchpin of the British Empire. In advocating the salvation of Indian women, British feminists established their claim for political emancipation as the moral saviours of empire. New Zealand, under selfgovernment, lay outside this redemptive vision. In 1888, the British Committee announced that it had 'determined to deal first with the case of the Crown Colonies'. The English social purity reformer Alfred Dyer endorsed their position, cancelling a planned Australasian tour to continue exposing 'licensed sin' in India. Nevertheless, with the colony's women enfranchised, from 1893 its value as an object lesson for metropolitan reformers dramatically increased. ${ }^{53}$

Fostered by women's organisations eager to maximise their electoral influence and contest their representation in foreign publications, enfranchised New Zealand women had a heightened awareness of their international reputation. Before the 1893 election, Kate Sheppard identified 'the disgraceful C.D. Act...repealed years ago [in Britain]' as an urgent concern, and reassured Josephine Butler of their commitment to the cause in $1894 .{ }^{54}$ Women's political associations adopted the cause swiftly, and the Liberal government introduced a repeal bill in June $1895 .{ }^{55}$ In the years since the New Zealand parliament had debated repeal, the imperial campaign sparked a constitutional crisis over the governance of India. Despite a House of Commons resolution mandating abolition in 1888 , officials across the empire defiantly maintained licensed prostitution. ${ }^{56}$ If not already informed about the surreptitious continuation of Indian regulation, New Zealand reformers were enlightened in November 1892, when the missionaries Katharine Bushnell and Elizabeth Andrew toured the colony. Fresh from their British Committee-sponsored investigative mission in northern India, they did not address the local Act, but on several occasions conjured 'a vivid picture of what native women suffer in India'. Early the following year the pair sensationally revealed the extent of the Indian regulatory system before a British parliamentary committee. ${ }^{57}$ 
As Antoinette Burton pointed out, colonial repeal struggles inflected British culture. Metropolitan feminists sought global abolition not only to ameliorate colonised women's lives, but also to counteract the threat of reinstated domestic regulation. ${ }^{58}$ In New Zealand, previously peripheral to Josephine Butler's project, women's enfranchisement coincided with a slump in the repeal movement as reformers' vigour abated in the face of colonial intransigence and European allies retreated from strict opposition to regulation. Many British feminists considered repeal intimately bound with suffrage activism, and the colony provided them with a perfect case study. Under universal suffrage, New Zealand became a flashpoint in the imperial struggle, an emblematic frontier where enfranchised women could outlaw contagious diseases regulation, and reinvigorate British campaigners. Adapting to these new circumstances, the British Committee reversed its founders' decision to leave the question of repeal to the selfgoverning colonies' discretion. Prompted by Mary Steadman Aldis, in December 1894, the Committee sought assurances from Kate Sheppard that women's groups were dedicated to repeal. The following year, it issued a similar appeal to the New Zealand parliament. ${ }^{59}$ In the meantime, 'impelled...by a certain fear that these recently enfranchised women might be in ignorance of the real issues of this question of regulation', Butler circulated a trenchant open letter explaining her expectations of New Zealand women. ${ }^{60}$ Remarking that 'the women of New Zealand are now in possession of the Parliamentary suffrage, they are the only women in the British Empire as yet who have it', she enumerated their 'great responsibility...to demand the repeal of a law which is an insult to womanhood'. After describing the British campaign, led by disenfranchised women, Butler expressed her envy at New Zealand women's privilege, and informed them that they acted on behalf of all 'Anglo-Saxon women':

It would be a bitter grief to us, and a subject of self-abasement as women if it could be said throughout the world that the first group of Anglo-Saxon women who possessed the vote had failed to use it in this great purifying work. But I believe better things of 
the women of New Zealand, and hope to hear of an early and serious uprising on their part against this wickedness. ${ }^{61}$

In an unlikely irony, the Auckland Star published the letter the day after the AWLL confirmed her suspicions by endorsing the Contagious Diseases Act. Their widely reported resolution, delivered at a meeting on 11 June and later reiterated, demanded that the Act be 'made applicable for men and women alike, and should be rigorously enforced' to protect 'posterity...[and] wives unhappily circumstanced'. ${ }^{62}$ Affiliated with the incumbent Liberal government, the AWLL's proposal mirrored those mooted by prominent politicians, but had never before been articulated by a women's organisation. Though the resolution sought to remove the sexual double standard encoded in the Act, the League's demand for the extension of state regulated prostitution was anathema to repealers. ${ }^{63}$ By 1895 , as the contagious diseases debate revealed, the unity engendered by the suffrage campaign began unravelling as women reverted to their class, political, and religious affiliations.

The AWLL had emerged in August 1894 following an acrimonious split within the AWPL. When the latter drew itself closer to the 'arch-conservative' National Association, vicepresident Eliza Collings and twenty others resigned to establish a rival organisation. Like its predecessor, the AWLL's manifesto concerned temperance, moral reform, and women's economic rights. Crucially, the new association distinguished itself from the middle-class Christian feminist nexus that dominated Auckland women's organisational culture (Elizabeth Caradus, one of the colony's few prominent working-class suffragists was another inaugural member) ${ }^{64}$ In September, Collings revealed the AWLL's prioritisation of class over gender politics:

They represented th[e] working women of Auckland along with the working men of Auckland. They could not separate the two...they should not blame the men for past failures, and...they must be moderate in the reforms they sought to bring about. ${ }^{65}$ 
Within days, more established women's political associations-vehemently opposed to party politics-repudiated the AWLL's stance, condemning the Act as a 'degrading abomination' and urging its members to retract the resolution. ${ }^{66}$ Reinforcing the feminist establishment's rejection of the AWLL, Annie Schnackenberg also registered her disapproval, and pledged the Auckland WCTU to 'leave no stone unturned till the disgraceful actions are swept from the Statute Books'. ${ }^{67}$ In addition to the opprobrium levelled by feminist organisations, other commentators voiced their dissatisfaction with the League's position. Prominent among these was Mary Steadman Aldis' husband William. Familiar with the transnational abolition campaign, he cast his criticism of the League in imperial terms, labelling it 'the first body of women [in the world], professing to be of decent character, which has given its sanction to the outrage on womanhood involved in the Act' ${ }^{68}$

Mainstream newspapers also cast the AWLL's resolution in an imperial light. Since enfranchisement, editorial pages often reflected on the international ramifications of feminist politics, though such interventions betrayed domestic partisanship rather than concern for women overseas. When the AWPL fractured in 1894 the New Zealand Herald instructed 'political women' to act moderately or risk 'prevent[ing] women in other parts of the empire from receiving the franchise'. ${ }^{69}$ In an editorial appended to Butler's letter, the pro-repeal Auckland Star argued the AWLL was unacquainted with the 'history of the subject or the part taken by enlightened women in Great Britain [to] oppose...this abominable law'. The paper further opined that 'capital will be made abroad of the unfortunate resolution', which constituted a 'deadly blow to the cause of woman suffrage throughout the Empire'. Moreover, the Star argued, for those who considered New Zealand a 'Better Britain', the AWLL's sin was not only their lack of solidarity: they had tarnished the colony's reputation by dragging 'the dirty subject from the obscurity to which it had properly [been] consigned' ${ }^{70}$ The AWLL's few supporters also recognised the imperial operation of contagious diseases legislation. The Herald 
argued universal suffrage would improve the Act's administration, mitigating the 'errors or abuses which may be possible among poor Hindoo women—who had no votes'. ${ }^{11}$ Going even further, the Observer declared that 'having led the British Empire in the matter of female franchise, there is no reason... why the women of New Zealand should not also lead the way in the matter of social reform [by endorsing the Contagious Diseases Act]' ${ }^{72}$

As the 1895 repeal bill sank in the Legislative Council and the scandal disappeared from the local press, New Zealand women's organisations began to receive correctives from their British counterparts. Informed of the incident by the Aldises, Josephine Butler spread the news across her reform network. ${ }^{73}$ Elizabeth Andrew, then staying near Butler in Switzerland, wrote to the Auckland WCTU 'deploring the action of the W.L. League in Auckland and asking for their address that they might send some literature on the subject'. ${ }^{74}$ The following month, the British Committee provided Kate Sheppard an Army Sanitary Commission report on venereal disease in India as ammunition against those 'who believe in the hygienic value of the C.D.A' ${ }^{75}$ In April 1895, Butler warned the British, Continental and General Federation that the movement was 'losing ground...power and missionary order' ${ }^{76} \mathrm{New}$ Zealand developments prompted the publication of her second appeal, lamenting the 'defection of women', in August. After republishing the AWLL's resolution in full, noting that it 'signalised their recent accession to electoral rights', Butler described the episode at length, culminating with her intervention. Uncharacteristically, she arranged for the pamphlet's circulation in New Zealand, following it with another open letter exhorting female voters to continue the struggle. ${ }^{77}$ The British social purity periodical Sentinel capitalised on the episode to spread unfounded rumours, intended to reinforce abolitionist sentiment at home and abroad. Several editorials in 1895 argued that, encouraged by the AWLL, the 1896 Intercolonial Medical Congress of Australasia would demand 'the energetic enforcement of the C.D. Acts throughout Australia and New Zealand'. The paper's editors also sought to force the World's WCTU to adopt a stronger line on regulated 
prostitution, arguing that a failure to contradict the 'strange rumours afloat...that the [New Zealand] branch...is in favour of the Bill' would 'irreparably ruin' the organisation. Encouraged by the Sentinel, fifteen branches of the British Women's Liberal Association wrote 'earnest letter[s] of remonstrance' condemning the AWLL and the Contagious Diseases Act, published and distributed in New Zealand by the Aldises in $1896 .^{78}$

Disquiet with New Zealand women's putative support for the Contagious Diseases Act extended beyond social purity circles. Reporting on the AWLL in October 1895, the influential feminist newspaper Woman's Signal explicitly linked repeal with women's enfranchisement. Edited by the suffragist Florence Fenwick Miller, the Signal demanded that 'our sisters in New Zealand do the right thing just now'. In her interpretation, the AWLL had undermined British women's reputation as political citizens. 'They have Woman's Suffrage on trial in the eyes of the English-speaking world, and deep will be the mischief...if they now disgrace it'. ${ }^{79}$ While they were not the voiceless 'women of the East' that served a rhetorical function in the British women's press, New Zealand women were unable to respond to the scandal in a timely fashion. ${ }^{80}$ Still in London, Kate Sheppard persuaded the Signal to qualify Miller's remarks. Whereas the Signal labelled the AWLL a 'large...federation of associations', Sheppard informed readers that women opposed the 'small and recently formed' League, and their dedicated opposition had inspired the 1895 repeal bill. ${ }^{81}$

Sheppard's distant compatriots were not afforded the same privilege, and felt compelled by Butler's 'stern' tactics to publicly rededicate themselves to the repeal cause. ${ }^{82}$ In June the Dunedin WFL explained 'the trend of opinion in our league' to Butler, and assured her 'that we quite expect the aid of the Government will be given in repealing the C.D. Act'. Following her accusation of women's 'defection' from abolitionism, the embarrassed Christchurch WCTU also reaffirmed its commitment to repeal. ${ }^{83}$ The Auckland Union took a less sanguine approach, 'deploring the need of a second appeal', and publicly registering their indignation that Butler 
and others had characterised the rogue resolution as orthodox opinion among New Zealand women. ${ }^{84}$ An independent collective of Auckland women responded to Butler in kind, sending open letters to Dawn and Sentinel. While declaring their fidelity to the repeal cause, the authors carefully reframed the debate, emphasising that the AWLL represented an errant minority. ${ }^{85}$ New Zealand served as a proxy for Butler's fears of obsolescence, but provided World's WCTU president Frances Willard a forum to vent her mounting frustration with the radical abolitionists. After seeking assurances from Sheppard, in late 1895 she congratulated New Zealand women for their steadfast opposition to the Contagious Diseases Act. Her letter, published their newspaper White Ribbon, noted: 'We are closely watched, and in spite of the fact that only one society, in one town, attempted to pass a disastrous resolution, all the women in New Zealand are blamed' ${ }^{86}$

Though it arrived too late to support the 1895 bill, Josephine Butler's choreographed intervention assisted the following year's repeal effort. As the Napier suffragist Emily Hill predicted, international feminist critique galvanised a parliament that largely disdained domestic feminist reformers. ${ }^{87}$ Announcing a repeal attempt in 1896, Premier Richard Seddon drew attention to observers 'outside the colony watching their conduct with regard to this measure'. After the Legislative Council dismissed his first bill, Seddon took the extraordinary step of introducing a second attempt in the same session, heralding the 'large number of communications' he had received 'from societies in the Mother-country, whose object was to get reform in the direction undertaken in this Bill' ${ }^{88}$ In a further testament to the sway of metropolitan opinion, Seddon tabled these letters in the House, and they were later published in pamphlet form. ${ }^{89}$ In advance of the repeal debates, the British Committee shipped 10,000 propaganda leaflets to New Zealand, prompting members to complain that their 'pigeonholes had been stuffed pretty full of pamphlets' from the Act's opponents, while Butler's rhetoric filtered into anti-regulationist speeches. The Bill's supporters, however, scorned domestic 
repealers, and used their gender to dismiss the campaign as frivolous, supported by venal politicians eager to court the new electorate. ${ }^{90}$ Lingering anti-feminist sentiment contributed to both bills' failure, heralding a backlash against women attempting to translate their claimed moral authority into political power. As Tracy Tulloch showed, opposing Councillors were disproportionately likely to have voted against women's suffrage in $1893 .{ }^{91}$

Thwarted three times by the Legislative Council, Seddon abandoned contagious diseases reform as a serious political ambition. Though the National Council of Women (NCW), formed in 1896, pressed for repeal, by 1900 White Ribbon's once frequent entreaties on the subject ceased. So too did British scrutiny. Although the LNA proclaimed that New Zealand had been one of 'the two great battlefields of this year', the reinstatement of Indian regulation in 1897 ended British reformers' focus on the colony. ${ }^{92}$ Parliament repealed the Act in 1910, responding not just to its feminist critics, but rising concerns about venereal diseases and national vitality. ${ }^{93}$ Just as Butler's suspicions regarding New Zealand women's sympathies were unfounded, so was her faith in the transformative power of the vote. In following decade, none of the objectives that feminist groups most ardently pursued - raising the age of consent to twentyone, allowing female parliamentary representation, wage equality, and securing married women's economic independence-reached fruition. Furthermore, the fêted 1890s social reforms occurred simultaneously in jurisdictions without female suffrage. ${ }^{94}$ Contrasting their post-suffrage optimism, New Zealand feminists tempered their enthusiasm on the international stage. Disheartened by their unspectacular progress, New Zealand's delegation to the International Council of Women's 1904 congress described the vote without legislative representation as a 'blunt weapon', and observed the difficulty 'where we have no initiative', in even determining 'what measures have resulted from [our]...partial share in legislation'. ${ }^{95}$

Josephine Butler's impassioned response to the Auckland Women's Liberal League's endorsement of the Contagious Diseases Act reveals asymmetries in the relationship between 
metropolitan and white colonial feminists in the nineteenth century. Brought to her attention by her reform network, Butler transmitted the news to her associates, issued a series of admonishments to New Zealand women, and orchestrated a lobbying effort that swayed colonial legislators when they debated repeal in 1896 . Her reaction to the pronouncement of a minor colonial organisation was not merely the product of misinformation by partisan local contacts. As the international repeal campaign ebbed, she broke the British Committee's silence on the self-governing colonies when an opportunity arose to bolster abolitionist sentiment. Overlooked in national and imperial histories of repeal, her intervention typified the close, yet uneven relationship between British and New Zealand feminists. In 1894, both encouraged by and uneasy with the ex-suffragists' assertions of women's newfound moral authority, Butler and her colleagues targeted New Zealand in an attempt to vindicate and reinvigorate the imperial campaign.

Following women's enfranchisement, New Zealanders-particularly feminist leadersemphasised the importance of women exemplifying their political citizenship for the benefit of overseas observers. Mimicking Butler's plea to the 'first group of [enfranchised] Anglo-Saxon women', in 1902, Margaret Sievwright reminded New Zealand women they had assumed 'the white woman's burden of responsibility in this corner of our great empire'. ${ }^{96}$ However, projecting this image as succour to British women proved difficult when the political establishment, and even - to Anna Stout's chagrin — female voters, resisted their agenda. It was further complicated by their fraught relationship with the metropolitan feminist and reform press, which appropriated colonial news for its own purposes, not always allied with the concerns of its distant subjects. Although white New Zealand women enjoyed the privileges of the coloniser, they felt that they were not trusted to 'correctly' exercise their political rights. ${ }^{97}$

In 1895, the desire to showcase the possibilities of female franchise remained strong, as did loyalties to the British feminists who inspired the suffrage struggle. Yet, amid the deferential 
apologies and public rededications to the repeal campaign, New Zealand women overlaid their response with hints of defiance and disappointment that their voices were seldom heard and often misrepresented in metropolitan debates. Two years later, World's WCTU vice-president Lady Henry Somerset's reprised the AWLL's proposal, advocating the official reinstatement of regulated prostitution in India to protect 'thousands of innocent women in England [from] a load of suffering'. Her remarks prompted Butler's public disavowal of the WCTU and almost disintegrated the organisation. Undaunted by the criticism they had endured, New Zealand members joined the clamour demanding her resignation. ${ }^{98}$ In time, British suffragettes would request their assistance, but in 1895 imperial domination, though challenged by New Zealand women's pioneer achievement, had not yet been overturned. ${ }^{99}$

\section{Acknowledgments:}

I would like to thank Lisa Plotkin and the staff at the Women's Library at the London School of Economics for assisting with archival research, and especially Lisa Ford and Ian Tyrrell for their help in the preparation of this manuscript.

\section{References:}

\footnotetext{
${ }^{1}$ Josephine Butler to Mary Priestman, 26 July 1895, Josephine Butler Letters Collection, 3JBL/34/39, Women's Library, London School of Economics (WL).

${ }^{2}$ See Antoinette Burton (1994) Burdens of History: British Feminists, Indian Women, and Imperial Culture, 1865-1915 (Chapel Hill: University of North Carolina Press).

${ }^{3}$ Raewyn Dalziel (1994) Presenting the Enfranchisement of New Zealand Women Abroad, in Caroline Daley and Melanie Nolan (Eds) Suffrage and Beyond: International Feminist Perspectives, (Auckland: Auckland University Press), pp. 43-46.

${ }^{4}$ Burton, Burdens of History, pp. 127-169.

${ }^{5}$ Barbara Caine (1998) International Links in Barbara Caine (Ed.), Australian Feminism: A Companion (Melbourne: Oxford University Press) p. 162.

${ }^{6}$ F.B. Smith (1971) Ethics and Disease in the Later Nineteenth Century: The Contagious Diseases Acts, Historical Studies, 15(57), pp. 118-120.

${ }^{7}$ Philippa Levine (2003) Prostitution, Race \& Politics: Policing Venereal Disease in the British Empire (London: Routledge), p. 1 .

8 Judith R. Walkowitz (1980) Prostitution and Victorian Society: Women, Class, and the State (Cambridge: Cambridge University Press), pp. 98-99.

${ }^{9}$ Burton, Burdens of History, pp. 1-32.
} 
${ }^{10}$ Antoinette Burton (1994) Rules of Thumb: British History and 'Imperial Culture' in Nineteenth and Twentieth-Century Britain, Women's History Review, 3(4), pp. 483-501; Levine, Prostitution, Race \& Politics, p. 4.

${ }^{11}$ Felicity Barnes (2012) New Zealand's London: A Colony and its Metropolis (Auckland: Auckland University Press), p. 6; Jane Carey and Jane Lydon (2014) Indigenous Networks: Historical Trajectories and Contemporary Connections, in Jane Carey and Jane Lydon (Eds), Indigenous Networks: Mobility, Connections and Exchange (New York: Routledge), p. 6.

${ }^{12}$ Peter J. Coleman (1982) New Zealand Liberalism and the Origins of the American Welfare State, Journal of American History, 69(2), pp. 372-391.

${ }^{13}$ Charlotte Macdonald (1986) The 'Social Evil': Prostitution and the Passage of the Contagious Diseases Act (1869), in Barbara Brookes, Charlotte Macdonald, and Margaret Tennant (Eds), Women in History: Essays on European Women in New Zealand (Wellington: Allen and Unwin/Port Nicholson Press), pp. 13-33; Jan Robinson (1984) Canterbury's Rowdy Women: Whores, Madonnas and Female Criminality, Women's Studies Journal, 1(1), pp. 6-25; Jan Robinson (1987) The Oldest Profession, in Shelagh Cox (Ed.), Public and Private Worlds: Women in Contemporary New Zealand (Wellington: Allen \& Unwin/Port Nicholson Press), pp. 181-188; T.C. Tulloch (1997) State Regulation of Sexuality in New Zealand 1880-1925 (PhD Thesis, University of Canterbury), pp. 188-246.

${ }^{14}$ Caroline Daley (2009) Introduction in Susan K. Martin, Caroline Daley, Elizabeth Dimock, Cheryl Cassidy, and Cecily Dimock (Eds), Women and Empire, 1750-1939: Primary Sources on Gender and Anglo-Imperialism, Volume II: New Zealand (Oxford: Routledge), p. xxiii. See also Felicity Barnes (2013) Pictorialism, Photography and Colonial Culture, 1880-1940, New Zealand Journal of History, 47(2), pp. 136-156; Charlotte Macdonald (2009) Intimacy of the Envelope: Fiction, Commerce, and Empire in the Correspondence of Friends Mary Taylor and Charlotte Brontë, c.1845-55 in Tony Ballantyne and Antoinette Burton (Eds), Moving Subjects: Gender, Mobility and Intimacy in an Age of Global Empire (Urbana and Chicago: University of Illinois Press), pp. 89-109.

${ }^{15}$ M.P.K. Sorrenson (1992) Māori and Pākehā in Geoffrey W. Rice (Ed.), The Oxford History of New Zealand, $2^{\text {nd }}$ ed., (Auckland: Oxford University Press), p. 156.

${ }^{16}$ Charlotte Macdonald (1990) A Woman of Good Character: Single Women as Immigrant Settlers in Nineteenth-Century New Zealand (Wellington: Allen \& Unwin), pp. 19-39, 173-188.

${ }^{17}$ Lyttelton Times, 4 March 1868, p. 1.

${ }^{18}$ New Zealand Parliamentary Debates (NZPD), Vol. 5, 1869, p. 421; Committees-Social Evil, Legislative Department (AEBE), series 18507, 62/1869/12, Archives New Zealand (ANZ), Wellington.

${ }^{19}$ NZPD, Vol. 6, 1869, pp. 396, 678.

${ }^{20}$ Jan Jordan (2010) Of Whalers, Diggers and 'Soiled Doves': A History of the Sex Industry in New Zealand in Gillian Abel, Lisa Fitzgerald, Catherine Healy, and Aline Taylor (Eds), Taking the Crime out of Sex Work: New Zealand Sex Workers' Fight for Decriminalisation (Bristol: Policy Press), p. 28; Levine, Prostitution, Race \& Politics, p. 235; Committees-Social Evil, AEBE, series 18507, 62/1869/12, ANZ.

${ }^{21}$ Levine, Prostitution, Race \& Politics, p. 323; NZPD, Vol. 6, 1896, p. 396.

${ }^{22}$ Contagious Diseases Act 1869 (NZ), s. 4; Levine, Prostitution, Race \& Politics, pp. 46-51.

${ }^{23}$ Macdonald, 'Social Evil', p. 25; Auckland Star (AS), 3 September 1886, p. 4; Oamaru Mail, 6 March 1885, p. 4; Press, 2 June 1885 , p. 2.

${ }^{24}$ Stevan Eldred-Grigg (1984) Pleasures of the Flesh: Sex \& Drugs in Colonial New Zealand 1840-1915 (Wellington: A.H. \& A.W. Reed), p. 35; Macdonald, 'Social Evil', p. 23; Margaret Tennant (1986) 'Magdalens and Moral Imbeciles': Women's Homes in Nineteenth-Century New Zealand, Women's Studies International Forum, 9(5), p. 493.

${ }^{25}$ William Pember Reeves (1902) State Experiments in Australia and New Zealand, Vol. 1, (London: Grant Richards), p. 103; Women and the Vote (Dunedin: Hocken Library, 1986).

${ }^{26}$ Woman's Signal (WS), June 1894 supplement, pp. 422-423; Englishwoman's Review, 16 July 1894, pp. 165-169.

${ }^{27}$ Kate Sheppard (1889) Address on the Subject of Woman Suffrage (Wellington: Evening Press Office), p. 8; Prohibitionist, 23 September 1893, p. 3. 
${ }^{28}$ New Zealand Herald (NZH), 12 October 1893, p. 5; Prohibitionist, 25 November 1893, p. 3; Prohibitionist, 9 December 1893, p. 3.

${ }^{29}$ For example see WS, June 1894 supplement, p. 423; WS, 21 June 1894, p. 432; Nottinghamshire Guardian, 18 August 1894 , p. 8; Bristol Mercury and Daily Post, 7 February 1895, p. 3.

${ }^{30}$ A.R. Grigg (1983) Prohibition and Women: The Preservation of an Ideal and a Myth, New Zealand Journal of History, 17(2), pp. 154-163; Linda Moore (2004) Gender Counts: Men, Women and Electoral Politics, 1893-1919 (MA Thesis, University of Canterbury), pp. 220-245. In 1896, 41.81 per cent of voters were female, and 37.83 per cent of voters supported the 'local option', less than the three-fifths majority required for any district to enact prohibition. In her statistical analysis of New Zealanders' voting preferences between 1893 and 1919, Moore determined that women were 'more likely to support prohibition measures than men...[but] did not necessarily favour prohibition over continuance'.

${ }^{31}$ Anna Stout to Margaret Windeyer, 9 February 1897, Windeyer Family Papers, MSS186/17, Mitchell Library, Sydney.

${ }^{32}$ Dalziel, Presenting the Enfranchisement of New Zealand Women Abroad, p. 47.

33 Press, 5 February 1894, p. 5. On Bakewell's opposition to women's enfranchisement and the temperance movement see Auckland Weekly News, 3 September 1892, p. 8; NZH, 23 August 1893, p. 3; NZH, 25 October 1893, p. 3.

${ }^{34}$ NZH, 26 March 1892, p. 5; Union Signal, 15 March 1894, p. 5. Emma Packe's failed attempt to enshrine the doctrine of atonement as a prerequisite of holding office generated fierce debate at the 1892 WCTU convention, and she soon left the union. Peter Lineham (2014) The Unexplained Religion of the WCTU, Pacific Journal of Baptist Research, 9(1), pp. 22-34. ${ }^{35}$ Prohibitionist, 19 May 1894, p. 3.

3613 June 1894, Auckland Minute Book (MB) 1889-1898, New Zealand Women's Christian Temperance Union (NZWCTU) Records, 79-057-08/03, Alexander Turnbull Library (ATL), Wellington; Prohibitionist, 19 May 1894, p. 3; Prohibitionist, 16 June 1894, p. 3.

${ }^{37}$ Prohibitionist, 14 July 1894, p. 3.

38 Isabel Somerset to Sheppard, 28 June 1894, Catherine Wilson Sheppard Papers Relating to Women's Franchise, ARC176/53/5, Canterbury Museum (CM), Christchurch.

${ }^{39}$ Prohibitionist, 19 May 1894, p. 3.

${ }^{40}$ Union Signal, 6 September 1894, p. 4.

${ }^{41}$ Caroline Daley (2005) Puritans and Pleasure Seekers, in Allison Kirkman and Pat Moloney (Eds), Sexualities in Aotearoa/New Zealand (Dunedin: Otago University Press), p. 51.

${ }^{42}$ Tulloch, State Regulation of Sexuality in New Zealand, pp. 197-200.

${ }^{43}$ AS, 4 May 1896, p. 4; Jenny Coleman (2008) Apprehending Possibilities: Tracing the Emergence of Feminist Consciousness in Nineteenth-Century New Zealand, Women's Studies International Forum, 31(6), pp. 471-472; Macdonald, A Woman of Good Character, p. 188.

${ }^{44}$ Minutes of the New Zealand Women's Christian Temperance Union at the First Annual Meeting (Wellington: Lyon \& Blair Printers, 1886), p. 14; Evening Post, 15 April 1890, p. 2; Press, 24 June 1890, p. 3; Press, 27 June 1893, p. 3.

${ }^{45}$ Phillida Bunkle (1980) The Origins of the Women's Movement in New Zealand: the Woman's Christian Temperance Union, 1885-1895, in Phillida Bunkle and Beryl Hughes (Eds), Women in New Zealand Society (Auckland: Allen and Unwin), p. 54; Ian Tyrrell (1991) Woman's World, Woman's Empire: The Woman's Christian Temperance Union in International Perspective, 1880-1930 (Chapel Hill: University of North Carolina Press), pp. 191-192.

${ }^{46}$ Prohibitionist, 7 October 1893, p. 4.

${ }^{47}$ See Charlotte Macdonald (2009) Suffrage, Gender and Sovereignty in New Zealand, in Irma Sulkunen, Seija-Leena NevalaNurmi, and Pirjo Markkola (Eds), Suffrage, Gender and Citizenship: International Perspectives on Parliamentary Reforms (Newcastle: Cambridge Scholars Publishing), p. 24.

${ }^{48}$ Sarah Dalton (1993) The Pure in Heart: The New Zealand Women's Christian Temperance Union and Social Purity, 1885 1930 (MA Thesis, Victoria University of Wellington), pp. 46-51; Minutes of the New Zealand Women's Christian Temperance Union at the First Annual Meeting, p. 14. 
${ }^{49}$ Prohibitionist, 15 July 1893, p. 3.

${ }^{50}$ Tulloch, State Regulation of Sexuality in New Zealand, pp. 201-204.

${ }^{51}$ AS, 4 June 1886, p. 2; Dawn, 1 July 1891, p. 10; Leader, 4 June 1887, p. 7; 26 June 1889, 10 July 1889, and 10 June 1890 , Auckland MB 1889-1898; M.S. Aldis to Millicent Garrett Fawcett, 29 November 1892, Women's Suffrage Collection, GB127.M50/1/2/180, Greater Manchester County Record Office. From the late 1880s Aldis was a regular contributor to Dawn, the British, Continental and General Federation's quarterly newspaper and Sentinel, a monthly British social purity newspaper edited by Alfred Dyer.

52 Josephine Butler (1887) The Revival and Extension of the Abolitionist Cause: A Letter to the Members of the Ladies' National Association (Winchester: John T. Dowsell), p. 3; Jane Jordan (2001), Josephine Butler (London: John Murray), pp. 240-249.

${ }^{53}$ Kenneth Ballhatchet (1980) Race, Sex and Class under the Raj: Imperial Attitudes and Policies and their Critics, 1793-1905 (New York: St Martin's Press), pp. 11-39; Burton, Burdens of History, pp. 1-32; Dawn, 1 November 1888, p. 11; 4 May 1888, Adelaide Minute Book 3 February 1887-7 August 1891, Woman's Christian Temperance Union of South Australia Records, SRG186/435/2, State Library of South Australia, Adelaide.

${ }^{54}$ Prohibitionist, 7 October 1893, p. 5; White Ribbon (WR), April 1896, p. 4.

${ }^{55}$ Star, 20 July 1893, p. 1; Otago Daily Times (ODT), 28 July 1894, p. 2; Evening Post, 11 July 1894, p. 2.

${ }^{56}$ Levine, Prostitution, Race \& Politics, pp. 91-141.

${ }^{57}$ ODT, 16 November 1892, p. 2; Southland Times, 18 November 1892, p. 2.

${ }^{58}$ Burton, Burdens of History, pp. 137-138.

59 (1896) Twenty-Fourth Annual Report of the Ladies National Association for the Abolition of Government Regulation of Vice for the Years 1894 and 1895 (London: J.W. Arrowsmith), pp. 25-26, 61.

${ }^{60}$ A Second Letter of Appeal and Warning from Josephine E. Butler to Members of the British, Continental, and General Federation for the Abolition of the State Regulation of Prostitution (London: Pewtress \& Co, 1895), p. 4.

${ }^{61} A S, 12$ June 1895, p. 4.

${ }^{62}$ Press, 13 June 1895, 5; $A S$, 26 June 1895, p. 5.

${ }^{63} A S, 25$ August 1894, p. 2; NZPD, 1896, Vol. 92, pp. 259-260. In 1896, the Liberal Premier Richard Seddon and his colleague Sir Robert Stout argued 'men and women ought to be reported, and steps taken to isolate them' under any replacement legislation.

${ }^{64}$ AS, 8 August 1894, p. 5; AS, 22 August 1894, p. 8; Sandra Coney (1986) Every Girl: A Social History of Women and the YWCA in Auckland 1885-1985 (Auckland: YWCA), pp. 6-8, 31-32; W.J. Gardner (1961), The Rise of W.F. Massey, 18911912, Political Science, 13(3), p. 10. Between 1895 and 1896 the AWPL strongly considered formalising its ties with the National Association. A resolution to rebrand itself as the 'Women's Branch of the National Association of New Zealand,' was unanimously passed in December 1895 but never enacted. Auckland Women's Political League Minutes 1892-1898, MSS2009/6/1, Special Collections, University of Auckland Library.

${ }^{65} \mathrm{NZH}, 19$ September 1894, p. 6.

${ }^{66} A S$, 27 June 1895, p. 2; NZH, 18 June 1895, p. 5; ODT, 2 July 1895, p. 4.

6726 June 1895, Auckland MB 1889-1898.

${ }^{68} \mathrm{NZH}, 17$ June 1895, p. 3.

${ }^{69} \mathrm{NZH}, 27$ August 1894, p. 4

${ }^{70} A S$, 12 June 1895, p. 4; $A S$, 24 June 1895, p. 4.

${ }^{71} \mathrm{NZH}, 27$ June 1895, p. 4.

72 Observer, 6 July 1895, p. 2.

${ }^{73}$ Butler to Priestman, 10 August 1895, Butler Collection, 3JBL/34/39, WL.

7425 September 1895, Auckland MB 1889-1898.

${ }^{75}$ Fanny Forsaith to Sheppard, 17 October 1895, Sheppard Papers, ARC176/53/7, CM. 
${ }^{76}$ A Letter of Earnest Appeal and Warning from Josephine E. Butler to the Members of the British, Continental and General Federation for the Abolition of the State Regulation of Prostitution (London: Pewtress \& Co, 1895), p. 3.

${ }^{77}$ Second Letter of Appeal, 3-6; Butler to Priestman, 10 August 1895; AS, 26 October 1895 supplement, p. 4.

${ }^{78}$ English Opinion Evoked by the Recent Resolution of the Auckland Women's Liberal League (Auckland: H. Brett, 1896); Sentinel, September 1895, pp. 127-128; Sentinel, October 1895, pp. 143-145; Sentinel, January 1896, p. 7; Sentinel, February 1896, p. 23; Sentinel, May 1896, p. 56.

79 WS, 17 October 1895, p. 249.

${ }^{80}$ Burton, Burdens of History, p. 169.

${ }^{81}$ Helen Hood to Sheppard, 28 November 1895, Sheppard Papers, ARC176/53/7, CM; WS, 12 December 1895, p. 378.

${ }^{82}$ Butler to Priestman, 10 August 1895, Butler Collection, 3JBL/34/39, WL.

${ }^{83}$ ODT, 29 June 1895, p. 8; Press, 11 October 1895, p. 4.

${ }^{84} 23$ October 1895, Auckland MB 1889-1898; WR, October 1895, p. 4.

${ }^{85}$ Dawn, April 1896, p. 8; Sentinel, April 1896, p. 48.

${ }^{86}$ Frances Willard to Sheppard, 14 August 1895, Sheppard Papers, ARC176/53/7, CM; Jordan, Josephine Butler, pp. 278-281; $W R$, November 1895, p. 5.

${ }^{87}$ Sentinel, February 1896, p. 23.

${ }^{88}$ NZPD, Vol. 92, 1896, pp. 259-260; Vol. 93, 1896, p. 465.

${ }^{89}$ Letters Received by the Premier from England Relative to the Repeal of the Contagious Diseases Act and the Raising of the Age of Consent (Wellington: John Mackay, 1896); 'Repeal of the Contagious Diseases Act, and the Raising of the Age of Consent', Appendix to the Journals of the House of Representatives (New Zealand), 1896, H-28, pp. 1-4.

${ }^{90}$ NZPD, 1896, Vol. 92, pp. 322-323; Vol. 94, 1896, pp. 527-532; 10 February 1896, British Committee Minute Book, Vol. 2, 13 November 1893-30 June 1897, British Committee of the Continental and General Federation for Abolition of Government Regulation of Prostitution Records, 3BGF/C/1, Box FL076, WL.

${ }^{91}$ Tulloch, State Regulation of Sexuality in New Zealand, pp. 214-215. Barbara Brookes provides a more thorough account of the Legislative Council's determined resistance to repealing the Contagious Diseases Act and the women's movement's concurrent attempt to raise the age of sexual consent. Brookes (1993) A Weakness for Strong Subjects: The Women's Movement and Sexuality, New Zealand Journal of History, 7(2), pp. 143-148.

${ }^{92}$ Caroline Brooks and Gay Simpkin (1975) A Bibliography of Articles Published in the White Ribbon, the Official Organ of the New Zealand Women's Christian Temperance Union 1895-1919 (Wellington: National Library of New Zealand), pp. 2223; Twenty-Fourth Annual Report of the Ladies National Association, p. 72.

${ }^{93}$ Bronwyn Dalley (1996) Lolly Shops 'of the red-light kind' and 'soldiers of the King': Suppressing One-Woman Brothels in New Zealand, 1908-1916, New Zealand Journal of History, 30(1), pp. 3-23.

${ }^{94}$ Caroline Daley (2010) What if Women had not Won the Vote in 1893, in Stephen Levine (Ed.), New Zealand as it Might Have Been 2 (Wellington: Victoria University Press), pp. 299-301.

${ }^{95}$ International Council of Women Reports and Addresses Given at the Third Quinquennial Reunion held in Berlin, June, 1904 (Boston: International Council of Women, 1909), pp. 62-63.

${ }^{96}$ Margaret Home Sievwright (1902) The Removal of the Civil and Political Disabilities of Women (Gisborne: Gisborne Times Office), p. 3.

${ }^{97}$ Angela Woollacott (2001) To Try Her Fortune in London: Australian Women, Colonialism, and Modernity (Oxford: Oxford University Press), p. 46.

98 The Times, 21 April 1897, p. 10; WR, January 1898, p. 8.

${ }^{99}$ For example see Sir Joseph Ward to Sheppard, 20 November 1910, Sheppard Papers, ARC176/53/17, CM. 